\title{
Global financial market and tools for its prediction
}

\author{
Tetyana Vasylieva ${ }^{1}$, Jan Chutka ${ }^{2, *}$ \\ ${ }^{1}$ Department of Finance and Entrepreneurship, Sumy State University, Ukraine \\ ${ }^{2}$ University of Zilina, The Faculty of Operation and Economics of Transport and Communications, \\ Department of Economics, Univerzitna 1, 01026 Zilina, Slovakia
}

\begin{abstract}
.
Research background: In today's modern world, we can constantly observe turbulent changes in every aspect of human life. These changes have also affected the area of financial markets, where we can identify a gigantic shift in the last few decades. In our article, we focused on the issue of trading in financial markets, the history of trading in contrast to the current situation, but especially the tool for predicting future price movements of financial instruments. In our article, we dealt with the issue of financial markets, their development and prediction tools.

Purpose of the article: The aim of our article was to provide a brief overview of the path that the financial markets area has taken in the recent past to the present day.

Methods: We used formal methods such as analysis and synthesis of theoretical findings and others.

Findings \& Value added: Based on the above-mentioned methods, we developed a clear framework for the development of financial markets, forecasting tools and specified the volume profile method and identified its strong relationship to the functioning of financial markets and the auction process itself. We consider the goal of the paper to be fulfilled and we believe it will bring a certain benefit of research in the given area.
\end{abstract}

Keywords: financial markets; prediction; volume profile

JEL Classification: $G 12 ; G 15 ;$; 17

\section{Introduction}

If we look closely at the financial markets, we can say that they have undergone great and turbulent developments since their inception. Rapid changes have occurred especially in recent decades, when, mainly due to scientific and technological progress in the field of IT, financial markets have become faster, more integrated, more interconnected and, most importantly, more efficient than in the past. Traders and investors have a wide range of new financial instruments, assets and especially their derivatives at their disposal, which can be used in their transactions in many ways. When we start talking about trading on the

\footnotetext{
* Corresponding author: jan.chutka@fpedas.uniza.sk
} 
financial markets, the tools of their prediction are inseparable. As the financial markets change, so do the methods for predicting and analyzing them. In our article, we would like to approach the issue of financial markets, their changes and the tools of their prediction [13].

\section{Profit as the primary aim of trading}

\subsection{History of trade}

According to Inna Sarkisyan (2007), trade as a special and independent economic activity began to emerge only at the interface of family and slave society after the separation of crafts from agriculture and towns from villages step back and 5.-8. For centuries, trade throughout Europe has declined [4]. A very important fact is that together with the development of trade as an independent, purposeful activity, there are also beginning to be specialized places where this trade takes place. Such places are mainly characterized by the fact that they concentrate potential market participants who want to participate in trade and pricing. In the history of trade, we can consider the emergence of the first stock exchanges very important. J. Vesela states that the first mentions of the origin of such exchanges can be found as early as the 12th and 13th centuries in Italy. The subject of trading was mainly bills of exchange, debt subscriptions and also coins of various currencies [5]. V. Pavlat states in his publication "Stock Exchange" that the Exchange got its present name after the banker Van der Buers, in front of whose house buyers and traders from all over Italy were concentrated and traded in the city of Bruges [6]. The establishment of the Amsterdam Stock Exchange in 1608 can be considered a very important step in the history of trade and stock exchanges. It became the first specialized stock exchange on which equity securities were traded [7]. Other stock exchanges were also established in other important shopping centers such as Paris, London, Hamburg or Berlin. Another milestone in the history of trading is the emergence of futures contracts and the associated emergence of the first stock exchange in Japan in Osaka in about 1650. P. Musilek states that the development of stock exchanges on the North American continent began at the turn of the 18th and 19th centuries. The official establishment of the secondary organized market in New York dates back to 1792. Shortly afterwards, however, the two largest derivatives exchanges in the world were established in the United States, namely the Chicago Board of Trade (CBOT) in 1848 and the Chicago Mercantile Exchange (CME) in 1874 [7].

\subsection{Modern financial markets}

The financial market is, in short, a set of instruments, procedures and licenses by which free funds are transferred from surplus entities (who own) to deficit entities that want to dispose of them. In simplicity, it is a place of conflict between the supply of free capital and the demand for free capital [8]. The financial market as such can be classified according to various aspects. The most commonly used method of breakdown is the breakdown by type of financial instruments traded on individual segments of the financial market, namely: the money market, the capital market, the insurance market, the foreign currency market and the precious metals market. As we begin to take a closer look at the issues of today's financial markets, we will see significant differences from their structure and especially their functioning in comparison with their situation in recent decades. Thanks to rapid scientific and technical progress, especially in the field of IT, today's financial markets perform their function much more efficiently than in the past [9]. The process of internationalization and subsequent globalization of financial markets has a great deal to do 
with this. Financial markets as we know them today are complex and narrowly integrated. Very often we are unable to pinpoint the boundaries between individual markets due to their interconnectedness and interdependence, especially with regard to derivatives of financial instruments. "Globalization is currently considered a key factor in the further development of the world economy. At the same time, it provokes considerable discussions both in theoretical circles, in government circles, as well as in the whole society [10]." The international interconnection of national economies, the internationalization and removal of barriers to trade, the creation of a global market and many other aspects of the globalization process are accelerating the development of the world economy. Through excellent expertise and extensive technical skills, China and India, which were developing countries until the middle of the 20th century, have shown considerable success. The process of globalization is changing the nature of competition and the conditions of competitiveness of individual countries and regions. The innovative revolution, especially in the field of information and communication technologies, can be considered as the main factors of globalization. They opened up space and provided opportunities for the worldwide development of economic activities of all kinds. The emergence of centralized exchanges has given rise to a wide range of techniques and methods aimed at predicting the development of the price of a traded asset. According to Mark Douglas, there are three basic types of stock market data analysis, namely fundamental, technical and mental analysis [11].

\section{Financial market prediction}

One of the most discussed areas of financial markets is the area dealing with methods and ways to successfully and as effectively as possible predict future price movements of financial instruments in financial markets. Fundamental analysis is based on the use of various economic factors to estimate the intrinsic values of various types of securities. In contrast, technical analysis relies on historical stock price data $[12,13]$. The general fundamental analysis finds its complex elements and essence in the work of Intelligent Investor by the well-known expert Graham. Extensive and detailed research has been conducted in the area of fundamental analysis. The rules of fundamental analysis presented by Graham in his publication were tested by various foreign authors such as Oppenheimer and Schlarbaum as well as Metghalchi, Chang and Marcucci and after their application came to a common conclusion and confirmed that this method can achieve higher than standard yields. They used a buy-and-hold strategy as a reference $[14,15]$. The first major academic study to examine technical analysis as an equivalent tool for analyzing the prices of financial assets and predicting future price movements of financial instruments in the financial market was the "Can Stock Market Forecasters Forecast?" By Alfred Cowles III.. The subject of this study was whether 45 professional entities were able to predict future price movements of financial instruments based on the rules of technical analysis [16]. However, Northcott disagrees with this statement, arguing that Munehisa Homma was the first to use the idea and concepts of technical analysis in the rice market in Japan in the 17th century. This 18 th century technique is now known as the "candlestick pattern" [17]. This statement is also supported by Turek in his book "Manual of Technical Analysis", where he adds that already in the 17th century, the Japanese began to use technical analysis for the needs of the rice trade. However, it also states that this type of technical analysis differed considerably from the American version, which was laid by Charles Dow between 1900 and $1902[18,19]$. 


\subsection{Technical analysis}

Since in the following chapters we will focus on a specific prediction method Volume profile, for these purposes we will describe in more detail the general concept of technical analysis on which this method is based. Generally speaking, there are two approaches that traders use as market access to determine whether the market will move up or down [20, 21]. It is a fundamental analysis and a technical analysis. It's a similar approach to buying a car. You can analyze its price, but on the other hand you can look at its engine, chassis and much more. While the fundamental analysis focuses on the economic information of companies, commodities or currencies, the technical analysis focuses on the chart of forecasting future price movements. Technical analysis is one of the most popular methods used by traders to determine business opportunities. There are three principles of technical analysis:

- The market shows everything

- Prices are moving in trends

- History is repeating

The technical analysis reflects a forecast of future price movements based on a survey of past prices. Technical analysts believe that if the financial instrument has grown recently, it may develop further in the future because it has an upward trend. There are many different techniques for identifying trends, but like weather forecasting, the results of a technical analysis do not cover all possible opportunities. Technical analysis can help investors predict what is likely to happen to prices over time [19].

\subsubsection{The market shows everything}

The technical analysis only considers price movements, ignoring the underlying factors, as it is assumed that all these factors affecting the market price are already included in these movements. So all that needs to be considered in the price itself. Of course, an unexpected event - such as a natural disaster or geopolitical tensions - can affect a particular market, but the technical analyst is not interested in this. The technical analyst focuses on the graph itself and the shapes of the candles and on the formations that appear on the graph.

\subsubsection{Prices are moving in trends}

The technical analysis assumes that price movements will follow trends. This means that after determining the trend, the future price movement is likely to go in the same direction as the trend than against it. Most technical trading strategies are based on this concept.

\subsubsection{History is repeating}

The cornerstone of technical analysis is the belief that history tends to repeat itself. For example, if the EURUSD rises before a Fed meeting, the trader buys before the next US interest rate decision. Technical analysts monitor historical price data to help them predict where prices are likely to go in the next period. This forms a place of support or resistance. Charts tend to create formations that have appeared historically, and analysis of past formations helps technical analysts predict future market movements. This principle focuses on the technical analyst's belief that trading is highly related to probability and that the analysis of historical formations gives the analyst an advantage over opening a trade. These shapes are known as candle formations. 


\section{Methods}

The profile of market, or "volume profile", has been used relatively recently, sometime in recent decades. It is a kind of technical analysis and its purpose is to show the market in terms of volume distribution at different price levels. The basic theoretical idea of this method is to analyze and display the structure of the realized volume of trades of a given financial instrument at a predetermined time horizon and in a predefined price interval. The idea on which the volume profile method is based is defined by basic economic processes such as the mutual interaction of supply and demand. The volume profile offers the trader or investor a detailed overview of at which price levels a large and, conversely, a small volume of transactions was carried out. Based on this information, the trader is able to interpret these price levels which price levels were very attractive to the market participant and which showed a reduced interest of traders to execute their orders on them. Such an interpretation of the individual levels is based on the basic microeconomic relationships between demand and supply. We can say that in the financial market there is a clash of buyers and sellers who are interested in trading a given financial instrument. These participants then create the demand and supply of the financial instrument. Essential information. which is the result of this interaction between supply and demand is the current price of the financial instrument. The resulting price can be considered as an equilibrium price until a new, more current price is created on the market. Based on microeconomic theories, we can assign certain properties to such an equilibrium price. The most important feature of the equilibrium price is that it is characterized by maximum sales volume. When applying a volume profile, the trader must predetermine certain variables that will partially define the given volume profile and determine its size. This dimension is defined by the time horizon and price range of the application. Traders use for analysis purposes volume profile in the form of a graphical representation as the histogram. The histogram is applied to the horizontal axis of the graph, and the corresponding columns of the histogram belong to the individual price levels and the volume that was realized at these levels. The whole essence of financial markets could be called "the search for a fair price". The market will not be located in an area where no one is interested in buying or selling. On the contrary, it will look for areas where buyers and sellers clash and are interested in fighting for a certain price. In such a case, there is a sideways movement in the markets (socalled chop), D-shaped profiles are formed and there is a balance in the markets. Movement to the side in the markets significantly outweighs the trend $(80 \%$ of movement in the markets is to the side). By recognizing such an area, we can more easily apply Sell methods such as Sell the High and Buy the Low. In the final, we witness the behavior of the market, reminiscent of the movement from one equilibrium area to another. Equilibrium is usually interrupted by a short-term trend, where the aggressive side of the fight wins [7,19,21].

\section{Results}

Based on a study of the theoretical background presented in the previous chapters of this paper, we can clearly see a huge shift in financial markets from their beginnings to the present day. Although the basic essence of financial markets remains the same, namely to enable and mediate the implementation of individual trades, progress is noticeable in almost every aspect. The biggest changes clearly occurred mainly in the efficiency of mediation and execution of trades in increasing the speed of executions to almost milliseconds, in the process of settlement of orders, especially in clearing procedures, but especially as is evident in the number of analytical tools available to today's traders. The volume of efficiency and speed of analytical tools of today's traders is incomparable with the situation a few decades ago. We attribute this shift mainly to progress in the field of IT. 
As we have mentioned today, traders now have tools at their disposal such as a volume profile, which penetrates its analysis to the basic economic level of the pricing process.

\section{Discussion}

Our paper deals with a very interesting way of predicting future price movements of financial instruments through the analysis of the structure of trading volumes at individual price levels. We have examined this approach in more detail because it has obvious connections with microeconomic theory. The volume profile as such should identify the maximum trading volume in a given interval, which should correspond to the equilibrium price on the market. Further research should be directed to an attempt to demonstrate this theory by deeply examining the effectiveness of the indicator we mentioned in relation to the overall market sentiment and the influencing non-price factors.

\section{Conclusion}

The aim of our article was to provide a brief overview of the path that the financial markets area has taken in the recent past to the present day. In the first chapter of our paper, we focused on trading as such, the history and the current state. In the next chapter, we focused on a brief overview of the tools for predicting the price movements of financial instruments. In the last chapter, we continued with a detailed description of the Volume profile and its relationship with basic microeconomic processes. Subsequently, based on the methods of formal logic, we formulated the advantages of using this method in the practice of predicting the price movements of financial instruments in financial markets. We consider the goal of the paper to be fulfilled and we believe it will bring a certain benefit of research in the given area.

This contribution is funded by a research project VEGA 1/0121/20: Research of transfer pricing system as a tool to measure the performance of national and multinational companies in the context of earnings management in conditions of the Slovak Republic and V4 countries.

\section{References}

1. Ashander, L., Kliestikova, J., Durana, P., Vrbka, J. (2019). The Decision-Making Logic of Big Data Algorithmic Analytics, Contemporary Readings in Law and Social Justice, 11(1), 57-62.

2. Podhorska, I., Siekelova, A., Olah, J. (2019). Earnings Analysis of SMEs: A Case Study in Slovakia. In K.S.Soliman (Ed.). Proceedings of the 33rd InternationalBusiness-Information-Management-Association (pp. 8706-8718). Norristown: USA.

3. Whittle, T., Gregova, E., Pohorska, I., Rowland, Z. (2019). Smart Manufacturing Technologies: Data-driven Algorithms in Production Planning, Sustainable Value Creation, and Operational Performance Improvement. Economics, Management, and Financial Markets, 14(2), 52-57.

4. Sarkisyan, I. (2007). History of trade. Retrieved from: https://dumfinanci.cz/clanky/183-historie-obchodu

5. Vesela, J. (2011). Investing in capital markets. 2nd, updated edition. Prague: Wolters Kluwer Czech Republic. 
6. Pavlat, V. (2003). Stock exchanges. 1st edition, Prague: University of Finance and Administration.

7. Musilek, P. (2011). Stock markets. 2., update and expand edition, Prague: Ekopress.

8. Rejnus, O. (2008), Financial markets. 1st edition. Ostrava: Key Publishing.

9. Hadas-Dyduch, M. (2019). China - Globalization world empirical analysis of connections, Ekonomicko-manazerske spektrum, 13(2), 81-88.

10. Heckova, J. (2008). The current state of Slovak industry and the prospects for its further development. Presov: Approved by the editorial board of the Faculty of Management of the University of Presov.

11. Douglas, M. (2010). Trading in the zone. 1. Edition. Teclice: IMPOSSIBLE s.r.o.

12. Chavarnakul, T., Enke, Ch. (2009), A literature review of technical analysis on stock markets. The Quarterly Review of Economics and Finance, 66, 115-126.

13. Teiceira, L.A., Oliviera, A.L.I.D. (2010). A method for automatic stock trading combining technical analysis and nearest neighbor classification. Expert Systems with Applications, 37(10), 6885-6890.

14. Oppenheimer, H.R., Schlarbaum, G.G. (1981). Investing with Ben Graham: An Ex Ante test of the efficient markets hypothesis. The Journal of Financial and Quantitative Analysis, 16(3), 341-360.

15. Metgalchi, M., Chang, Y.H., Marcucci, J. (2008), Is the Swedish stock market efficient? Evidence from some simple trading rules. International Review of Financial Analysis, 17(3), 475-490.

16. Cowles, A. (1933). Can stock market forecasters forecast? Econometrica, 1(3), 309324.

17. Northcott, A. (2009). The complete guide to using candlestick charting: How to earn high rates of return-safely. Atlantic Publishing Group, Inc.

18. Kovacova, M., Kliestik, T., Valaskova, K., Durana, P., Juhaszova, Z. (2019). Systematic review of variables applied in bankruptcy prediction models of Visegrad group countries. Oeconomia Copernicana, 10(4), 743-772.

19. Turek, L. (2011), Technical Analysis Manual 1 edition, Prague: CZECHWEALTH, s.r.o.

20. Siekelova, A., Podhorska, I. (2020). Earnings Indicators under the Condition of Globalization. SHS Web of Conferences, 74, Art. No. 01031.

21. Svabova, L., Durica, M. (2016). A closer view of the statistical methods globally used in bankruptcy prediction of companies. In T. Kliestik (Ed.). Proceedings of the 16th international scientific conference on globalization and its socioeconomic consequences (2174-2181). University of Zilina: Slovakia. 